\title{
Performance of the Boiler and To Improving the Boiler Efficiency Using Cfd Modeling
}

\author{
K. Sampath Kumar Reddy, Dr B. Veerabhadra Reddy \\ 1 (Mechanical Engineerig, G.Pulla Reddy Engineerig College (Autonomous) /Jntu Anantapur, India) \\ 2 (Mechanical Engineerig, G.Pulla Reddy Engineerig College (Autonomous)/Jntu Anantapur, India)
}

\begin{abstract}
The power sector is one of the sectors of the India's economy. The development of the country to a large extent is dependent on the growth of this sector. Through the progress of the power sector during the past four decades has been sustainable, the power industry has been unable to fulfill primary obligation of production quality power supply in required quantity. We did our project in Stage- 4, Unit -7 of Dr. Narla Tata Rao Thermal Power Station, Vijayawada and analyzed the performance of the boiler of the above-mentioned unit of capacity 500MW. Our project was mainly concerned with the Boiler Operations \& Maintenance Department $(O \& M)$. Initially, we calculated the performance and efficiency of the boiler. The Computational Fluid Dynamics (CFD) approach is utilised for the creation of a two-dimensional model of the economizer coil. Using mild steel material in the economizer part it gives better performance compared with the carbon steel material. The fluid flow temperature, pressure is increase and velocity is decrease field of fluid flow within an economizer tube using the actual boundary conditions have been analyzed using CFD tool. So the boiler performance will be increased. And the experimental setup is from Dr. NTTPS, Vijayawada having the unit no IV of $500 \mathrm{MW}$ energy generations.
\end{abstract}

Keywords: Two pass boiler, Boiler efficiency, CFD modeling, Economizer

\section{Introduction}

In a coal based power plant, coal is transported from coal mines to the power plant by railway wagons or in a merry-ground system. Coal is unloaded from the wagons to a moving underground conveyor belt. This coal is not uniform size. So it is taken to the Crusher house and crusher having size is $20 \mathrm{~mm}$. From the crusher house the coal is either stored in dead storage. And the crushed coal storage in the raw coal bunker in the boiler house. Raw coal from the raw coal bunker is supplied to the Coal Mills by a Raw Coal Feeder. The coal mills or pulverizes the coal to 200 mesh size. The powdered coal from the coal mills is carried to the boiler in coal pipes by high pressure hot air. The pulverized coal air mixture is burnt in the boiler in the combustion zone. CFD modeling is a good tool to improve the efficiency of economizer. To change the material of the economizer using mild steel material.

\section{Boiler Performance}

The boiler efficiency by "Losses Method" or "Indirect Method" can be calculated by considering a varied number of factors such as unit load, feed water flow at economizer inlet, dry bulb temperature, wet bulb temperature, fly ash, bottom ash, gross calorific value, calorific value, total secondary air flow, total primary air flow, total air flow, total main stream flow, carbon, nitrogen, hydrogen, oxygen, moisture, etc.

\subsection{BOILER AND AUXILIARIES}

A Boiler or steam generator essentially is a container into which water can be fed and steam can be taken out at desired pressure, temperature and flow. This calls for application of heat on the container. For that the boiler should have a facility to burn a fuel and release the heat. The functions of a boiler thus can be stated as:-

1. To convert chemical energy of the fuel into heat energy

2. To transfer this heat energy to water for evaporation as well to steam for superheating.

In the Power Plant Boiler, Coal is burnt to heat up the water. The fuel is burnt inside the Boiler, whereas the water which is heated runs in tubes on the surface of the Boiler. Thermal power plant boilers are different from other boilers because of the complexity of the process and different types of system involve in the entire combustion process. The complexity of the system is basically addressed in terms of efficiency of the boiler. The primary aim of any thermal combustion system is to maximize the efficiency. i.e., net output energy we get, by input energy. The boiler designed in Thermal Power Plant serves the above end. In Boilers, differential heating takes place, and each area of the boiler has got different temperature. To maximize efficiency it is important to construct/assemble water tube in the way to maximize heat absorption by conduction, which gives rise to different process. 


\title{
2.2 SPECIFICATIONS OF BOILER USING THIS PROJECT
}

\section{TYPE OF BOILER}

Two pass boiler, pressure of this boiler $=176 \mathrm{~kg} / \mathrm{cm}^{2}$ temperature of the boiler $=545^{\circ} \mathrm{C}$

capacity of power output of the plant $=500 \mathrm{MW}$

Fuel used in the plant $=$ coal

calorific value of fuel $==8054 \mathrm{kcal} / \mathrm{kg}$

$\mathrm{GCV}$ of coal $=3703 \mathrm{kcal} / \mathrm{kg}$

\subsection{STEPS INVOLVED IN THE PROJECT}

1. TAKE THE VALUES OF CONTROL ROOM

2. CALCULATE THE LOSSES OF BOILER

3. COMPARE DESIGN EFFICIENCY

4. CHANGE THE MATERIAL OF THE ECONOMIZER

5. USING CFD MODELING

\subsection{THEORETICAL EQUATIONS}

\section{Equations}

\author{
$\mathrm{GCV}$ of coal $=3703 \mathrm{kcal} / \mathrm{kg} \quad \mathrm{CV}$ of coal $=8054 \mathrm{kcal} / \mathrm{kg}$ \\ UN-BURNT CARBON LOSSES \\ LOSS $1=\left(\right.$ Carbon in ash ${ }^{*} \mathrm{CV}$ of coal $\left.* 100\right) / \mathrm{GCV}$ of coal
}

LOSS DUE TO MOISTUR IN FUEL

Sensible heat of water vapor $=1.855 *($ AFGTAPH- 25$)+2442+42.5 *(25-$ WT $)$

$$
\text { Loss } 2=\left(\mathrm{SHWV}^{*} \mathrm{MIF}\right) /\left(\mathrm{GCV}^{*} 4.186\right)
$$

\section{LOSS DUE TO HYDROGEN}

$\% \mathrm{H}$ in the fuel $=2.70 \%$

Loss $3=(9 * \mathrm{HIF} * \mathrm{SHWV}) /(\mathrm{GCV} * 4.186)$

\section{LOSS DUE TO CO}

Average flue gas CO2 @ APH outlet=14.48\%

Average flue gas $\mathrm{CO} @ \mathrm{APH}$ outlet $=0.00 \%$

$\% \mathrm{C}$ in the fuel $=46.11 \%$

$\mathrm{CV}$ of $\mathrm{CO}=2415 \mathrm{kcal} / \mathrm{kg}$

$\mathrm{GCV}=3703 \mathrm{kcal} / \mathrm{kg}$

Carbon in ash $/ \mathrm{kg}$ of coal $=0.001$

Loss $4=(\mathrm{ACOAPH} * 7 * \mathrm{CVCO} *(\mathrm{PCF}-100 * \mathrm{GCV}) / 3 /(\mathrm{ACDAPH}+\mathrm{ACOAPH}) / \mathrm{GCV})$

\section{LOSS DUE TO MOISTURE IN AIR}

Moisture in air $=0.0165$ [Psy. Chart]

Reference air temp $=28^{\circ} \mathrm{C}$

Avg flue gas temp @ APH outlet $=132.375^{\circ} \mathrm{C}$

Avg flue gas $\mathrm{O} 2 @$ APH outlet $=4.86 \%$

Avg flue gas N2@ APH outlet $=80.66 \%$

Stoichiometric air $=(2.66(\mathrm{PCF}-(\mathrm{CIA} * 100))+(7.937 * \mathrm{PHF})+(0.996 * \mathrm{PSF})-\mathrm{POF}) / 23.2$

Excess air $=1+($ AOAPH-ACOAPH/2) $/[0.2682 *$ ANAPH-(AOAPH-ACOAPH) $]$

Total moisture in air $=$ Stoichiometric air*Excess air*Moisture in air

Loss $5=\mathrm{TMA}^{*} 1.88 *(\mathrm{AFGAPHO}-\mathrm{RAT}) * 100 /(\mathrm{GCV} * 4.186)$

\section{DRY GAS LOSSES}

Total air flow

Ratio of SA to air flow

Ratio of PA to air flow

Weighted temp of air

GCV

Weight of dry gas

Sensible heat of dry gas

Loss $6=\left(\mathrm{SHDG}^{*} 100\right) /\left(\mathrm{GCV}^{*} 4.186\right)$

\section{OTHER LOSSES}

Loss due to sensible heat in fly ash

$$
\begin{aligned}
& =1821 \mathrm{t} / \mathrm{hr} \\
& =1127 / 1821=0.61 \\
& =697 / 1821=0.38 \\
& =45.73^{\circ} \mathrm{C} \\
& =3703 \mathrm{kcal} / \mathrm{kg} \\
& =0.27 \\
& =\left(\mathrm{WDG}^{*} \operatorname{SHFG}^{*}(132.375-45.73)\right)
\end{aligned}
$$


Temp of fly ash $=120^{\circ} \mathrm{C}$

$\%$ ash in coal $=34 \%$

Distribution of fly ash $=90 \%$

Specific Heat of fly ash $=0.16 \mathrm{kcal} / \mathrm{kg} / \mathrm{C}$

Loss due to fly ash $=$ AIC $/ 100 *$ DFA $/ 100 *$ SHFA $*(T F A-R A T) * 100 / G C V$

Loss due to Bottom Ash $=\mathrm{AIC} / 100 * \mathrm{DBA} / 100 * \mathrm{SHFA} *(\mathrm{TBA}-\mathrm{RAT}) * 100 / \mathrm{GCV}$

Loss due to sensible heat in Economizer $=\mathrm{AIC} / 100 * \mathrm{DDA} / 100 * \mathrm{SHFA}^{*}\left(\mathrm{TEDA}^{*} \mathrm{RAT} * 100\right) / \mathrm{GCV}$

TOTAL LOSSES

$=$ LOSS1+LOSS2+LOSS3+LOSS4+LOSS5+LOSS6+LOSS7+LOSS 8

Efficiency $\%=100-$ total losses

\begin{tabular}{|c|c|}
\hline UN-BURNT CARBON LOSSES & $=0.260 \%$ \\
\hline LOSS DUE TO MOISTUR IN FUEL & $=2.44 \%$ \\
\hline LOSS DUE TO HYDROGEN & $=4.001 \%$ \\
\hline LOSS DUE TO CO & $=0 \%$ \\
\hline LOSS DUE TO MOISTURE IN AIR & $=0.164 \%$ \\
\hline DRY GAS LOSSES & $=4.618 \%$ \\
\hline OTHER LOSSES & $=0.329 \%$ \\
\hline RADIANT LOSSES & $=0.24 \%$ \\
\hline $\begin{aligned} \text { Boiler efficiency }(\%) & =100-12.052 \\
& =87.948 \%\end{aligned}$ & \\
\hline
\end{tabular}

4.1 EXPERIMENTAL SET UP

\section{Analysis Of The Economizer}

4.1.1 Specification of Economizer Coil

$\begin{array}{ll}\text { Material } & : \text { MILD STEEL } \\ \text { Length of coil } & : 274 \mathrm{~mm} \\ \text { Outer diameter of the coil } & : 37.5 \mathrm{~m} . \mathrm{m} \\ \text { Thickness of the coil } & : 5.3 \mathrm{~mm} \\ \text { Total length of the coil } & : 54252 \mathrm{~m} \\ \text { Inner diameter } & : 27.5 \mathrm{~mm} \\ \text { Volume of the economizer } & : 110 \mathrm{~m}^{3}\end{array}$

\subsubsection{Geometry Of Economizer Coil}

\begin{tabular}{|l|l|l|l|}
\hline Sr. No. & Input Parameters & Value & unit \\
\hline 1 & Inlet temp of feed water & $\mathbf{2 1 0}$ & ${ }^{\circ} \mathrm{C}$ \\
\hline 2 & Out let temp of feed water & $\mathbf{2 5 0}$ & ${ }^{\circ} \mathrm{C}$ \\
\hline 3 & Mass flow rate of feed water & $\mathbf{1 . 3 5 9}$ & $\mathrm{Kg} / \mathrm{sec}$ \\
\hline
\end{tabular}

4.1.3 Thermal properties of mild steel
Density
: $7850 \mathrm{~kg} / \mathrm{m}^{3}$
Specific heat
: $475 \mathrm{j} / \mathrm{kg}^{\mathrm{o}} \mathrm{k}$
Thermal conductivity
: 0.044 watt $/ \mathrm{mm}^{\circ} \mathrm{k}$

4.2 PERFORMANCE OF MILD STEEL COIL

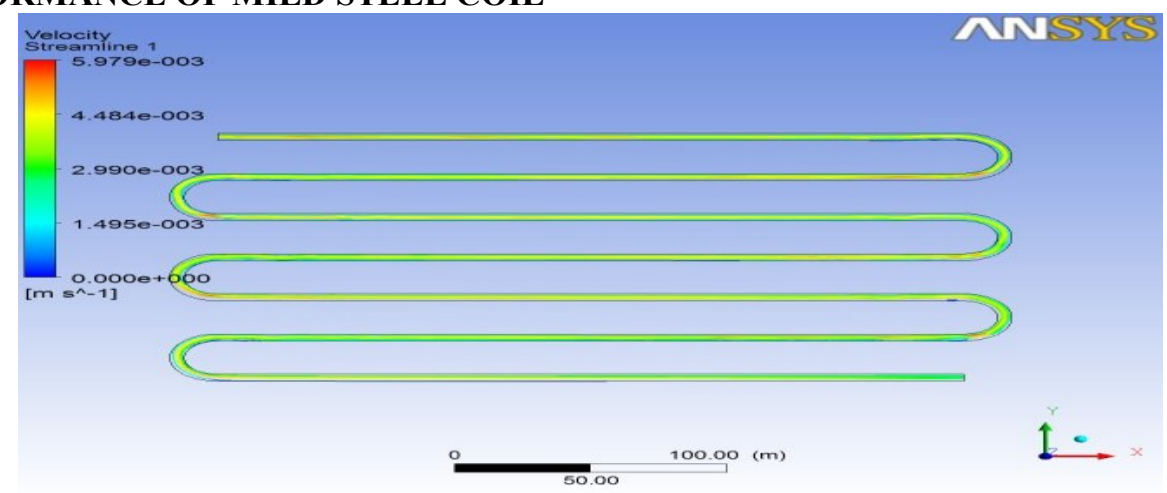

Fig1: mild steel velocity flow diagram 
Using Computational Fluid Dynamics (CFD), mild steel material in the economizer part in which velocity is decreased. But the temparature and pressure will be increased. so the mild steel material gives the better performance of the boiler.

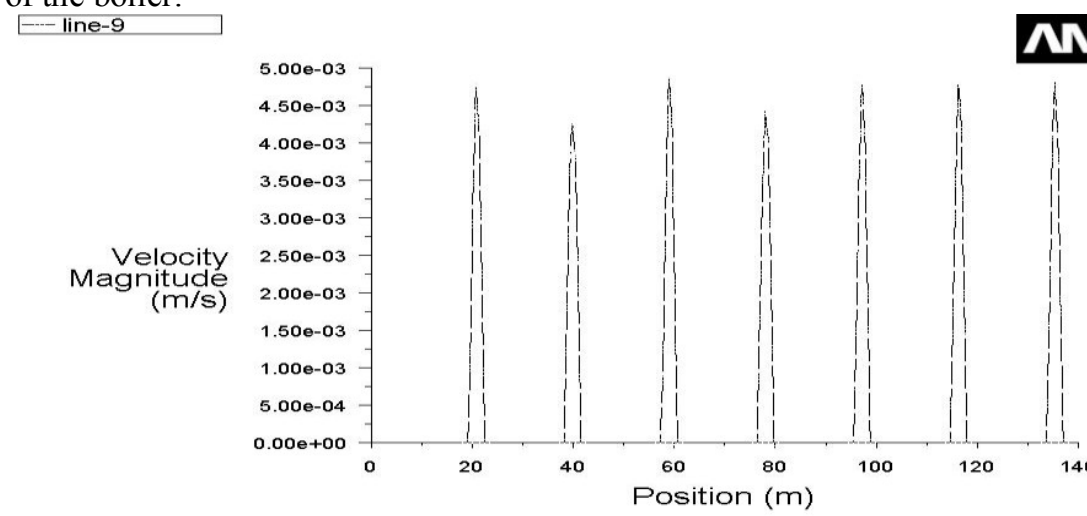

Velocity Magnitude

Sep 14, 2013
ANSYS FLUENT 12.0 (2d, dp, pbns, lam)

Fig 2: mild steel velocity graph

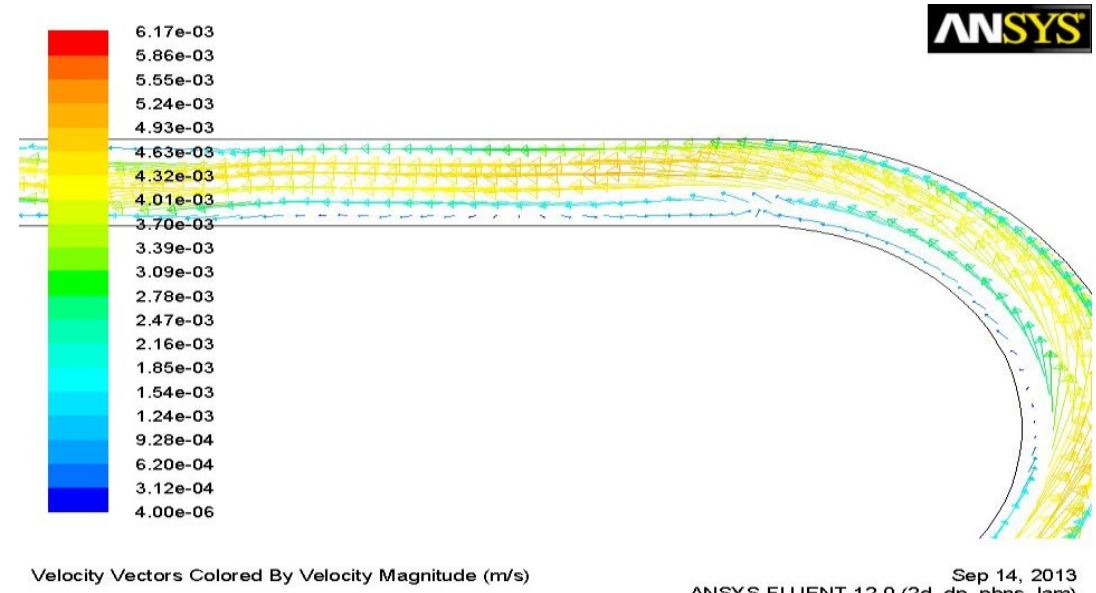

Fig 4: mild steel pressure diagram

Using mild steel material in CFD analysis the fluid flow in the economizer tube is increased. And pressure drop is less

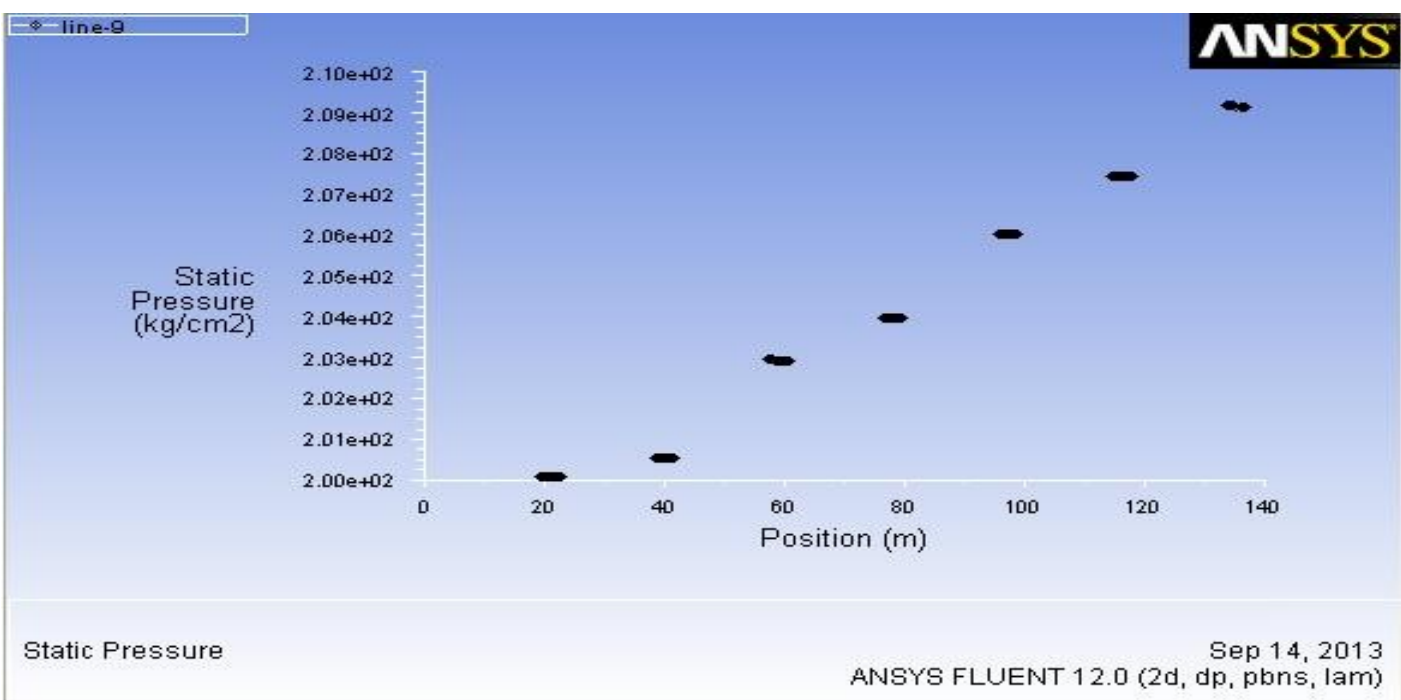

Fig 5: pressure graph 
The pressure contour of economizer in a vertical plane along its length in X-Z plane is shown in Figure4. The inlet pressure is low in economizer coil, which may be due to low temperature of feed water. The pressure of feed water at in the tube is higher at outlet and increases as it moves towards outlet. The high pressure gradient along the tube length is due to friction between feed water and the tube wall.

\section{Conclusion}

Conclusion derived from the data related to the boiler. The efficiency is calculated using indirect method (losses method). To change the economizer material of the boiler, the practical efficiency of boiler is $87.948 \%$. A method for predicting the pressure, velocity \& temperature distribution in the tube type economizer associated with coal fired boiler developed by using CFD. The CFD model may be used to optimize its thermal performance by varying the location in the economizer and in turn improve the performance of boiler. And due to changing the material of economizer such as mild steel. Out let pressure of the economizer is increased and temperature is not varied but velocity is decreased due to using the mild steel. Finally the boiler efficiency is increased.

\section{References}

[1]. A Text Book of Internal Combustion Engines: by Rajput, Laxmi publications.

[2]. A Text Book of Thermal Engineering by R.K. Rajput, Laxmi publications.

[3]. A Text Book of Design data Hand book by S.Md.Jalaludeen, Anuradha Publications.

[4]. Suhas V Patankar "Numerical Heat Transfer and Fluid Dynamics".

[5]. P.K.NAG“Power Plant Engineering”, 2006, Tata McGraw-Hill Publication. 